\title{
Membrane Fouling Controlled by Adjustment of Biological Treatment Parameters in Step-Aerating MBR
}

\author{
Dimitra C. Banti ${ }^{1, *(\mathbb{D})}$, Manassis Mitrakas ${ }^{2}$ (D) and Petros Samaras $^{1}$ (D) \\ 1 Laboratory of Technologies of Environmental Protection and Utilization of Food By-Products, Department of \\ Food Science and Technology, International Hellenic University, GR-57400 Thessaloniki, Greece; \\ samaras@ihu.gr \\ 2 Laboratory of Analytical Chemistry, Department of Chemical Engineering, \\ Aristotle University of Thessaloniki, GR-54124 Thessaloniki, Greece; mmitraka@cheng.auth.gr \\ * Correspondence: bantidim@gmail.com
}

check for updates

Citation: Banti, D.C.; Mitrakas, M.; Samaras, P. Membrane Fouling Controlled by Adjustment of Biological Treatment Parameters in Step-Aerating MBR. Membranes 2021, 11, 553. https://doi.org/10.3390/ membranes 11080553

Academic Editor: Gaetano Di Bella

Received: 6 July 2021

Accepted: 20 July 2021

Published: 22 July 2021

Publisher's Note: MDPI stays neutral with regard to jurisdictional claims in published maps and institutional affiliations.

Copyright: (c) 2021 by the authors. Licensee MDPI, Basel, Switzerland. This article is an open access article distributed under the terms and conditions of the Creative Commons Attribution (CC BY) license (https:/ / creativecommons.org/licenses/by/ $4.0 /)$.

\begin{abstract}
A promising solution for membrane fouling reduction in membrane bioreactors (MBRs) could be the adjustment of operating parameters of the MBR, such as hydraulic retention time (HRT), food/microorganisms (F/M) loading and dissolved oxygen (DO) concentration, aiming to modify the sludge morphology to the direction of improvement of the membrane filtration. In this work, these parameters were investigated in a step-aerating pilot MBR that treated municipal wastewater, in order to control the filamentous population. When $\mathrm{F} / \mathrm{M}$ loading in the first aeration tank $\left(\mathrm{AT}_{1}\right)$ was $\leq 0.65 \pm 0.2 \mathrm{~g} \mathrm{COD} / \mathrm{g} \mathrm{MLSS} / \mathrm{d}$ at $20 \pm 3{ }^{\circ} \mathrm{C}, \mathrm{DO}=2.5 \pm 0.1 \mathrm{mg} / \mathrm{L}$ and $\mathrm{HRT}=1.6 \mathrm{~h}$, the filamentous bacteria were controlled effectively at a moderate filament index of 1.5-3. The moderate population of filamentous bacteria improved the membrane performance, leading to low transmembrane pressure (TMP) at values $\leq 2 \mathrm{kPa}$ for a great period, while at the control MBR the TMP gradually increased reaching $14 \mathrm{kPa}$. Soluble microbial products (SMP), were also maintained at low concentrations, contributing additionally to the reduction of TMP. Finally, the step-aerating MBR process and the selected imposed operating conditions of HRT, F/M and DO improved the MBR performance in terms of fouling control, facilitating its future wider application.
\end{abstract}

Keywords: wastewater treatment; filamentous microorganisms; membrane bioreactor; membrane fouling; operating conditions

\section{Introduction}

Membrane bioreactors (MBRs) have been widely used during the last decades for wastewater treatment worldwide in large-scale $\left(\geq 10,000 \mathrm{~m}^{3} / \mathrm{d}\right)$ or even in super-largescale $\left(\geq 100,000 \mathrm{~m}^{3} / \mathrm{d}\right)$ plants, due to their various advantages, such as excellent effluent quality [1], occupation of small land area, low hydraulic retention time (HRT), higher solids retention time (SRT) and lower sludge production [2-4]. However, they present a major disadvantage that resides in energy consumption, which is attributed to the membrane fouling problem [5-7]. Membrane fouling is caused by the accumulation and deposition of activated sludge substances on the surface and in the pores of the membrane [8-12]. According to a recent research work [13], the combination of colloids and SMP (Soluble Microbial Products) -of protein-like and polysaccharide-like substances [14]- of activated sludge mixed liquor are the main parameters that worsen membrane fouling, while colloids play an even more decisive role. Membrane fouling leads to an increase in trans-membrane pressure (TMP) by reducing membrane permeability [3].

Extensive studies have been performed aiming to predict membrane fouling [15], to explain the membrane fouling mechanism [16-19], as well as to confront it [20-22]. According to such research works, gradual deposition and aggregation of SMP in the pores of the membrane caused irreversible membrane fouling, having, as a result, the pore blockage and increase of fouling rate and/or the detachment of aggregates in the 
permeate [16]. Moreover, according to past research activity [23,24], the filamentous bacterial population, known until today for causing bulking sludge problems in wastewater treatment processes, was manipulated through a modified MBR configuration and achieved to confront effectively the membrane fouling problem. However, this work needs to be optimized by further research.

According to some research works [25,26], a high Food/Microorganisms (F/M) ratio or Organic Loading Rate (OLR) induced the generation of SMP and more bound extracellular polymeric substances (EPS), resulting in a decrease of sludge filterability and lower filtration index. On the other hand, low Dissolved Oxygen (DO) increased filaments concentration and especially Type 0041 and M. parvicella [27,28]. Regarding the favorable DO concentration, it has been reported that the limitation or deficiency of DO was often responsible for the proliferation of filamentous bacteria in activated sludge processes [29,30]. However, on the other hand, [31] also reported that an increase in the DO levels from $1-2.5 \mathrm{mg} / \mathrm{L}$ to $3.5-5.7 \mathrm{mg} / \mathrm{L}$ under thermophilic conditions $\left(55^{\circ} \mathrm{C}\right)$ led to an increase in the filaments level.

Furthermore, a decrease of HRT from $24 \mathrm{~h}$ to $18 \mathrm{~h}$ [32], resulted in the release of EPS from the bacterial cells, which was responsible for the rise in SMP and sludge deflocculation. Nevertheless, according to the authors SMP rise was also attributed to other unstable operating conditions and not necessarily to the decreased HRT. Reduction of HRT from $12 \mathrm{~h}$ to $5 \mathrm{~h} \mathrm{[26],} \mathrm{also,} \mathrm{caused} \mathrm{the} \mathrm{growth} \mathrm{of} \mathrm{filamentous} \mathrm{bacteria} \mathrm{and} \mathrm{the} \mathrm{formation} \mathrm{of} \mathrm{large}$ and irregular flocs. However, too high HRT also led to the accumulation of foulants [26,32]. Short SRT of $10 \mathrm{~d}$ [33] or $23 \mathrm{~d}$ compared to high SRT of $40 \mathrm{~d}$ [34] harmed membrane fouling due to high concentrations of SMP and EPS, mainly in the form of polysaccharides [35]. At shorter SRT, the concentrations of deposited EPS on the membrane were much higher in comparison to higher SRT. Although prolonged SRT minimized excess biomass production, too long SRT ( $>60 \mathrm{~d}$ ) accelerated fouling due to large amounts of foulants and high sludge viscosity $[34,36]$.

Regarding the correlation of filamentous bacteria to SMP, EPS and sludge characteristics, it has been reported that filamentous bacteria density had no significant effect on bound extracellular polymeric substances (bound EPS, $\mathrm{r}_{\mathrm{p}}=-0.343, p=0.080$ ) and soluble microbial products (SMP, $\left.\mathrm{r}_{\mathrm{p}}=0.221, p=0.267\right)$ [37]. However, they had an important impact on floc size $\left(\mathrm{r}_{\mathrm{p}}=0.944, p=0.000\right)$ and floc structure $\left(\mathrm{r}_{\mathrm{p}}=-0.752, p=0.000\right)$. A high filamentous index contributed to the formation of larger flocs loosely structured and vice versa. Therefore, according to this research work, although filamentous bacteria can change the floc morphology, their effect on the membrane-fouling rate might be negligible. However, more recent work has discovered that EPS content and components were changed during filamentous bulking [38]. Especially, during sludge bulking, proteins and polysaccharides of EPS were gradually decreased, sludge hydrophobicity reduced, and surface negative charge increased. However, no information has been given about the fate of the SMP in bulking sludge conditions.

Considering the operating parameters of the MBRs, which affect the membrane foulants, significant research work has been carried out on MBR process to reduce membrane fouling, including contradictory conclusions or shortcomings. Previous work identified the crucial role of filamentous bacteria for membrane fouling control [23,24]. However, as filamentous bacteria present a significantly lower adsorption rate of soluble components, at the typical wastewater treatment processes their population is diminished due to the faster adsorption rate of the other floc-forming bacteria. The step-aeration process focuses on the modification of biological treatment parameters to decrease floc-forming bacteria absorption rate, favoring, in turn, the development of filamentous bacteria. Thus, this work aims to optimize operating conditions towards minimization of fouling, using controlled filamentous population, by adjusting the F/M loading, HRT and DO in the two aerated tanks of a step-aerating MBR. Moreover, the effect of filamentous bacteria on activated sludge characteristics and sludge metabolism products, such as SMP, which are the keyfoulants of the filtration membranes, was investigated to achieve the membrane fouling 
reduction. The step-aerating MBR process that is proposed by this work to control filamentous population, is a clean and cost-effective solution to reduce membrane fouling in MBRs. The step-aerating MBR reduces the operating cost of the MBR, as the frequency of the chemical cleanings and replacements of the fouled membranes are minimized. Moreover, this advantageous process for MBRs is not based on any chemical addition-a solution highly recommended by researchers nowadays $[39,40]$ - but only on the modification of operational conditions, offering therefore an additional economic and environmental benefit. By the proposed methodology of control of the filamentous population, the bulking sludge problem, which is usually attributed to the overgrowth of filamentous microorganisms, is also solved, and therefore a beneficial solution could be given for conventional wastewater treatment units too.

\section{Materials and Methods}

\subsection{Step-Aerating and Control MBR Set-Up}

The step-aerating pilot-scale membrane bioreactor presented in Figure 1, was consisted of two in-series aerated tanks: the first aeration tank $\left(\mathrm{AT}_{1}\right)$ of working volume $5 \mathrm{~L}$ and the second aeration tank $\left(\mathrm{AT}_{2}\right)$ of working volume $15 \mathrm{~L}$. The dissolved oxygen in both aerated tanks was regulated at $2.5 \pm 0.1 \mathrm{mg} / \mathrm{L}$. A hydrophilic flat sheet microfiltration (MF) membrane module, further described in Table S1, was submersed in the membrane tank (MT). Intense aeration was provided to the bottom of the MT to scour the cake layer from the membrane's surface with an air sparging rate of $10 \mathrm{~L} / \mathrm{min}\left(5.5 \mathrm{~m}^{3} / \mathrm{m}^{2} \cdot \mathrm{h}\right)$. The filtration was carried out by a filtration step of $10 \mathrm{~min}$ duration followed by a pause step of $2 \mathrm{~min}$. The MBR was located in a closed and protected tank, where the temperature was controlled at $20 \pm 3{ }^{\circ} \mathrm{C}$ in order not to affect the process.

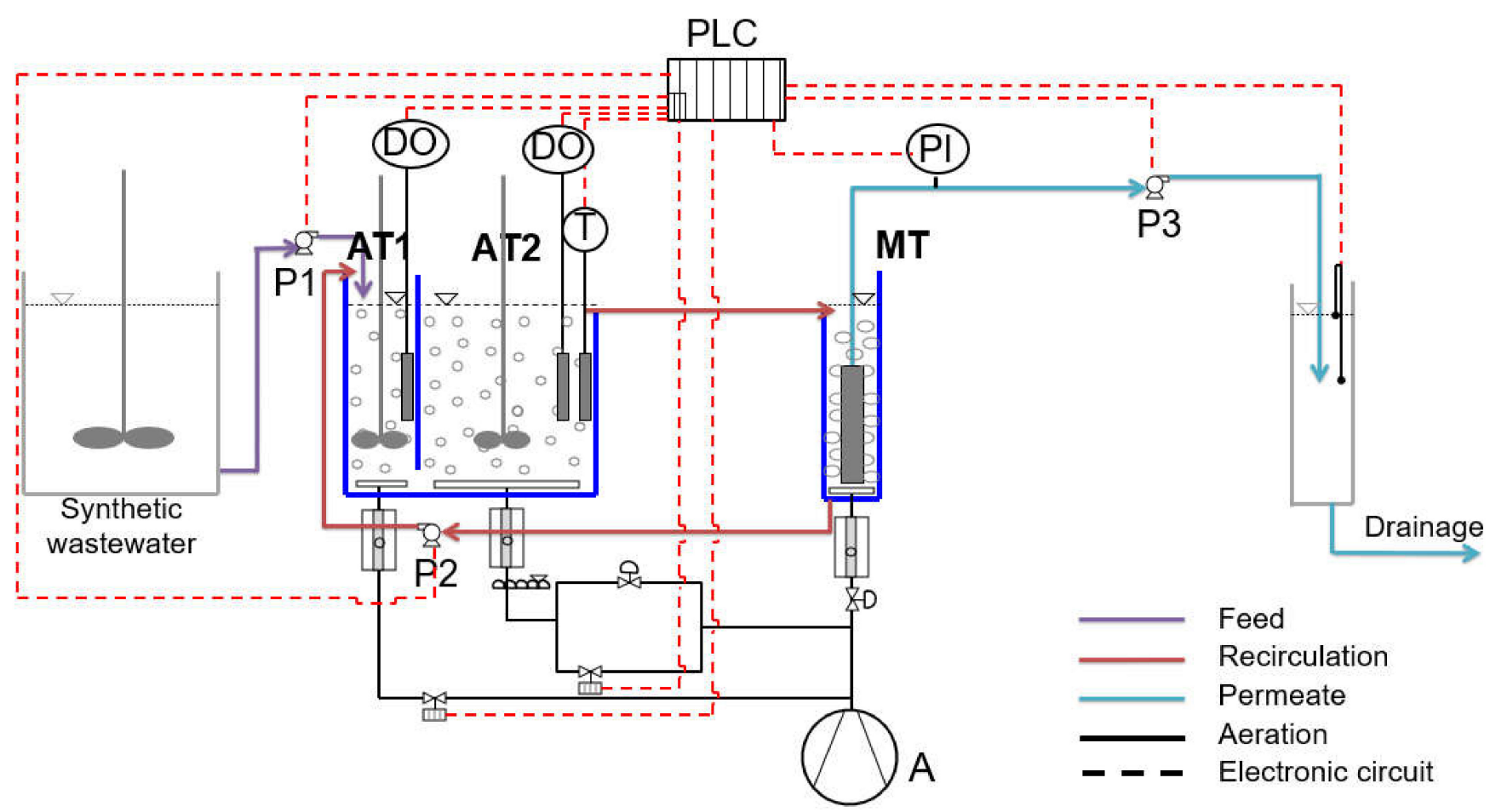

Figure 1. Flowchart of the step aerating MBR with two in-series aerated tanks, the $\mathrm{AT}_{1}(5 \mathrm{~L})$ and the $\mathrm{AT}_{2}(15 \mathrm{~L})$, followed by the membrane tank MT (5 L).

The MBR contained DO meters, an air compressor (CO), a thermometer and three peristaltic pumps, from which $\mathrm{P}_{1}$ was the feed pump of the influent synthetic wastewater $\left(\mathrm{Q}_{\text {in }}=0.9 \mathrm{~L} / \mathrm{h}\right), \mathrm{P}_{2}$ was the recirculation pump $\left(\mathrm{Q}_{\mathrm{r}}=2.2 \mathrm{~L} / \mathrm{h}\right)$ and $\mathrm{P}_{3}$ was the effluent pump $\left(\mathrm{Q}_{\text {eff }}=1.1 \mathrm{~L} / \mathrm{h}\right)$. The operating parameters, such as TMP, DO, $\mathrm{P}_{1}, \mathrm{P}_{2}, \mathrm{P}_{3}$ and temperature $(\mathrm{T})$ were recorded and controlled by a Programmable Logic Controller (PLC, 
Eutech Instruments, Singapore) using SCADA software (Simantec, Siemens (Munich, Germany), Version 14).

Synthetic wastewater was prepared two times per week to feed the MBR and contained glucose, corn starch, $\mathrm{NH}_{4} \mathrm{Cl}$, peptone, $\mathrm{KH}_{2} \mathrm{PO}_{4}, \mathrm{MgSO}_{4} \cdot 7 \mathrm{H}_{2} \mathrm{O}, \mathrm{MnSO}_{4} \cdot \mathrm{H}_{2} \mathrm{O}$ and $\mathrm{FeSO}_{4} \cdot 7 \mathrm{H}_{2} \mathrm{O}$ in the concentrations described further in [13]. $\mathrm{pH}$ was controlled at 7.0-7.5, adding $\mathrm{NaHCO}_{3}$. The chemical oxygen demand (COD) value of synthetic wastewater was ranged at $890 \pm 120 \mathrm{mg} / \mathrm{L}$. At the beginning of the MBR operation, the tanks were filled with activated sludge mixed liquor taken from a full-scale wastewater treatment plant of central Macedonia in Greece. An adjustment period of about $10 \mathrm{~d}$ was used to acclimate synthetic wastewater to the activated sludge process. Throughout the duration of the experiment only one membrane was used, which was never cleaned or replaced, as no total membrane fouling was observed.

Mixed liquor suspended solids (MLSS) in the step-aerating MBR were controlled at $6000 \pm 1500 \mathrm{mg} / \mathrm{L}$. The food/microorganisms (F/M) loading was, also, controlled at $0.65 \pm 0.20 \mathrm{~g} \mathrm{COD} / \mathrm{g}$ MLSS $/ \mathrm{d}$ in the $\mathrm{AT}_{1}$ and $0.03 \pm 0.01 \mathrm{~g} \mathrm{COD} / \mathrm{g}$ MLSS $/ \mathrm{d}$ in the $\mathrm{AT}_{2}$. The F/M ratio in the total MBR unit was equal to $0.13 \pm 0.04 \mathrm{~g}$ COD $/ \mathrm{g}$ MLSS $/ \mathrm{d}$.

For comparison needs, a control MBR was operated in parallel with the step-aerating MBR, which had similar operating conditions, with, however, a basic difference, that it consisted of a single aerobic chamber of $20 \mathrm{~L}$ working volume, followed by a membrane tank of $5 \mathrm{~L}$ working volume. In more detail, the membrane tank contained a similar submerged flat sheet microfiltration membrane module with the step-aerating MBR. The control MBR was constantly fed with synthetic wastewater of the same composition as the step-aerating MBR, having an influent COD equal to $850 \pm 76 \mathrm{mg} / \mathrm{L}$. MLSS concentration was equal to $6000 \pm 1000 \mathrm{mg} / \mathrm{L}$, while dissolved oxygen concentration was controlled at the typical value of $2.5 \pm 0.1 \mathrm{mg} / \mathrm{L}$. The temperature was, also, controlled at $20 \pm 3^{\circ} \mathrm{C}$ in order not to affect the process. The F/M ratio in the control MBR was $0.12 \pm 0.03 \mathrm{~g}$ COD $/ \mathrm{g}$ MLSS $/ \mathrm{d}$. Since the control MBR operated only for comparative reasons, the only parameters that were measured were TMP, COD, MLSS and Filamentous Index. A comparable summary table of the operating conditions of the step-aerating MBR and control MBR is presented in Table 1 , where many parameters are described in the form of average \pm standard deviation.

Table 1. Operating parameters of the step-aerating MBR and control MBR units.

\begin{tabular}{|c|c|c|c|}
\hline Operating Parameters & $\begin{array}{l}\text { Step-Aerating } \\
\text { MBR-Stage } 1\end{array}$ & $\begin{array}{l}\text { Step-Aerating } \\
\text { MBR-Stage } 2\end{array}$ & Control MBR \\
\hline Working time, $\mathrm{d}$ & 0-81 & $82-121$ & 47 \\
\hline $\mathrm{DO}_{\mathrm{AT} 1}, \mathrm{mg} / \mathrm{L}$ & $2.5 \pm 0.1$ & $1.2 \pm 0.5$ & $2.5 \pm 0.1$ (at the unique AT) \\
\hline $\mathrm{DO}_{\mathrm{AT} 2}, \mathrm{mg} / \mathrm{L}$ & $2.5 \pm 0.1$ & $2.5 \pm 0.4$ & - \\
\hline $\mathrm{F} / \mathrm{M}_{\mathrm{AT} 1}, \mathrm{~g} \mathrm{COD} / \mathrm{g} \mathrm{MLSS} / \mathrm{d}$ & \multicolumn{2}{|c|}{$0.65 \pm 0.20$} & $0.14 \pm 0.03$ (at the unique AT) \\
\hline $\mathrm{F} / \mathrm{M}_{\mathrm{AT} 2}, \mathrm{~g} \mathrm{COD} / \mathrm{g} \mathrm{MLSS} / \mathrm{d}$ & \multicolumn{2}{|c|}{$0.03 \pm 0.01$} & - \\
\hline $\mathrm{F} / \mathrm{M}_{\mathrm{tot}}, \mathrm{g} \mathrm{COD} / \mathrm{g} \mathrm{MLSS} / \mathrm{d}$ & \multicolumn{2}{|c|}{$0.13 \pm 0.04$} & $0.12 \pm 0.03$ \\
\hline Recirculation rate/Feed rate & \multicolumn{2}{|c|}{ 2.4:1 } & $2.4: 1$ \\
\hline $\begin{array}{c}\mathrm{HRT}_{\mathrm{AT} 1}, \mathrm{~h} \text {, based on } \mathrm{Q}_{\text {in }}+\mathrm{Q}_{\mathrm{r}} \\
\left(\mathrm{HRT}_{\mathrm{AT} 1}, \mathrm{~h} \text {, based on } \mathrm{Q}_{\mathrm{in}}\right)\end{array}$ & \multicolumn{2}{|c|}{$1.6(5.5)$} & 6.5 (22) (at the unique AT) \\
\hline $\begin{array}{c}\mathrm{HRT}_{\mathrm{AT} 2}, \mathrm{~h} \text {, based on } \mathrm{Q}_{\text {in }}+\mathrm{Q}_{\mathrm{r}} \\
\left(\mathrm{HRT}_{\mathrm{AT} 2}, \mathrm{~h} \text {, based on } \mathrm{Q}_{\mathrm{in}}\right)\end{array}$ & \multicolumn{2}{|c|}{$4.8(17)$} & - \\
\hline $\mathrm{HRT}_{\text {tot }}, \mathrm{h}$ & \multicolumn{2}{|c|}{28} & 28 \\
\hline SRT, d & \multicolumn{2}{|c|}{$30 \pm 5 \mathrm{~d}$} & $30 \pm 5 d$ \\
\hline MLSS, mg/L & \multicolumn{2}{|c|}{$6000 \pm 1500$} & $6000 \pm 1000$ \\
\hline Temperature, ${ }^{\circ} \mathrm{C}$ & \multicolumn{2}{|c|}{$20 \pm 3^{\circ} \mathrm{C}$} & $20 \pm 3{ }^{\circ} \mathrm{C}$ \\
\hline
\end{tabular}

\subsection{Determination of Physicochemical Parameters}

$\mathrm{COD}$ (Chemical oxygen demand), $\mathrm{N}-\mathrm{NH}_{4}, \mathrm{~N}-\mathrm{NO}_{3}$ and total $\mathrm{N}$ were measured for influent synthetic wastewater as well as the permeate using Hack-Lange LCK kits and a DR-2800 spectrophotometer for a sample per week. Furthermore, MLSS were measured by applying standard methods [41] for a sample per week. 


\subsection{Critical Flux Determination and Stabilization of the Reduction Tendency of the Permeate Flux}

Aiming to control membrane fouling and maintain a sustainable operation, critical flux was measured for both MBR units, defining the flux below which mainly reversible fouling occurs $[42,43]$. Therefore, the critical flux of each MBR was evaluated using the flux-step method [42,43] and it was found to be slightly greater than $10.2 \mathrm{Lmh}$ for both of them. Therefore, the MBRs were adjusted to operate in subcritical flux conditions, at $10 \mathrm{Lmh}$ and thus the influent $\left(\mathrm{Q}_{\text {in }}\right)$, recirculation $\left(\mathrm{Q}_{\mathrm{r}}\right)$ and effluent flowrates $\left(\mathrm{Q}_{\text {eff }}\right)$ was adjusted at $0.9,2.2$ and $1.1 \mathrm{~L} / \mathrm{h}$, respectively. The $Q_{\text {eff }}$ remained constant throughout the whole duration of the experiment. The difference in values between $\mathrm{Q}_{\text {in }}$ and $\mathrm{Q}_{\text {eff }}$ was $0.2 \mathrm{~L} / \mathrm{h}$ as the permeate flux was intermittent with an operation step of $10 \mathrm{~min}$ followed by a pause step of $2 \mathrm{~min}$. Therefore, the flows were properly adjusted to have an equilibrium in the MBR unit.

Directing to keep flux $\mathrm{Q}_{\text {eff }}$ constant, despite the increasing pumping pressure (TMP) in the membrane as a result of the gradual membrane fouling, a tank having level gauges was added at the end of the unit (Figure 1). In this tank, the flow rate was measured and when the flow was decreased (due to the increased pumping pressure in the membrane), the peristaltic pump $\mathrm{P}_{3}$ was commanded through PLC to increase its speed.

\subsection{Determination of Soluble Microbial Products (SMP)}

SMP were extracted using a physical extraction method as described by [16,44], while the SMP extracts were further analyzed to determine their protein and carbohydrate content. The Dubois photometric method was applied to measure their content in carbohydrates [45], in duplicate for each measurement, whereas a modified Lowry method was used to measure protein concentration [46], in triplicate for each sample, because of the sensitivity of the measurement. Bovine serum albumin (BSA, Sigma Aldrich) and glucose (Panreac) were used to calibrate protein and carbohydrate measurement respectively.

\subsection{Filamentous Index (FI) Measurement and Characterisation of Filamentous Microorganisms}

Filamentous Index (FI) was used, according to the Eikelboom method [27,28], to measure the population of filamentous microorganisms in the activated sludge mixed liquor of the MBR units. For the FI measurement, a Light Sheet Microscope (LSM, Observer Z1, Zeiss, Oberkochen, Germany) was used mainly in 100× magnification, whereas in some cases $50 \times$ and $200 \times$ magnifications were, also, used to take a better view of the samples. In filamentous index measurement, $\mathrm{FI}=0$ corresponds to no filaments coming out of the sludge flocs, whereas FI $=5$ corresponds to infinite filaments. ZEN software for microscope and imaging was used to edit the images, creating tiff image files. FI was measured for mixed liquor samples from all the tanks of both MBR units and they were found similar for the tanks of each MBR unit, as both MBRs were in balance. Gram staining and Neisser staining procedures [28] were, also, performed using the Light Sheet Microscope (LSM, Observer Z1, Zeiss) in 200× magnification to identify filamentous microorganisms.

\section{Results}

\subsection{Adjustment of Operating Conditions in the Step-Aerating MBR Unit}

The operating conditions at the $\mathrm{AT}_{1}$ of the step-aerating $\mathrm{MBR}$ were controlled at a high $\mathrm{F} / \mathrm{M}$ loading of $0.65 \pm 0.2 \mathrm{~g}$ COD/g MLSS/d and a typical DO concentration of $2.5 \pm 0.1 \mathrm{mg} / \mathrm{L}$, whereas, at the $\mathrm{AT}_{2}$, too low $\mathrm{F} / \mathrm{M}$ of $0.03 \pm 0.01 \mathrm{~g}$ COD $/ \mathrm{g}$ MLSS $/ \mathrm{d}$ and a typical DO of $2.5 \pm 0.1 \mathrm{mg} / \mathrm{L}$ was supplied. DO values were maintained at $2.5 \pm 0.1 \mathrm{mg} / \mathrm{L}$ for about 3 months (81 days) in both $\mathrm{AT}_{1}$ and $\mathrm{AT}_{2}$ chambers aiming to facilitate the biological treatment process and this stage of 81 days is called hereafter Stage 1. Following, $\mathrm{DO}$ was decreased in the $\mathrm{AT}_{1}$ at $1.2 \pm 0.5 \mathrm{mg} / \mathrm{L}$ aiming to study its effect on filamentous growth, SMP concentration and membrane fouling, while $\mathrm{DO}$ at the $\mathrm{AT}_{2}$ was kept constant at $2.5 \pm 0.4 \mathrm{mg} / \mathrm{L}$ throughout the experiment (Figure 2). The stage between the 82nd day and until the total membrane fouling will be called hereafter Stage 2. 


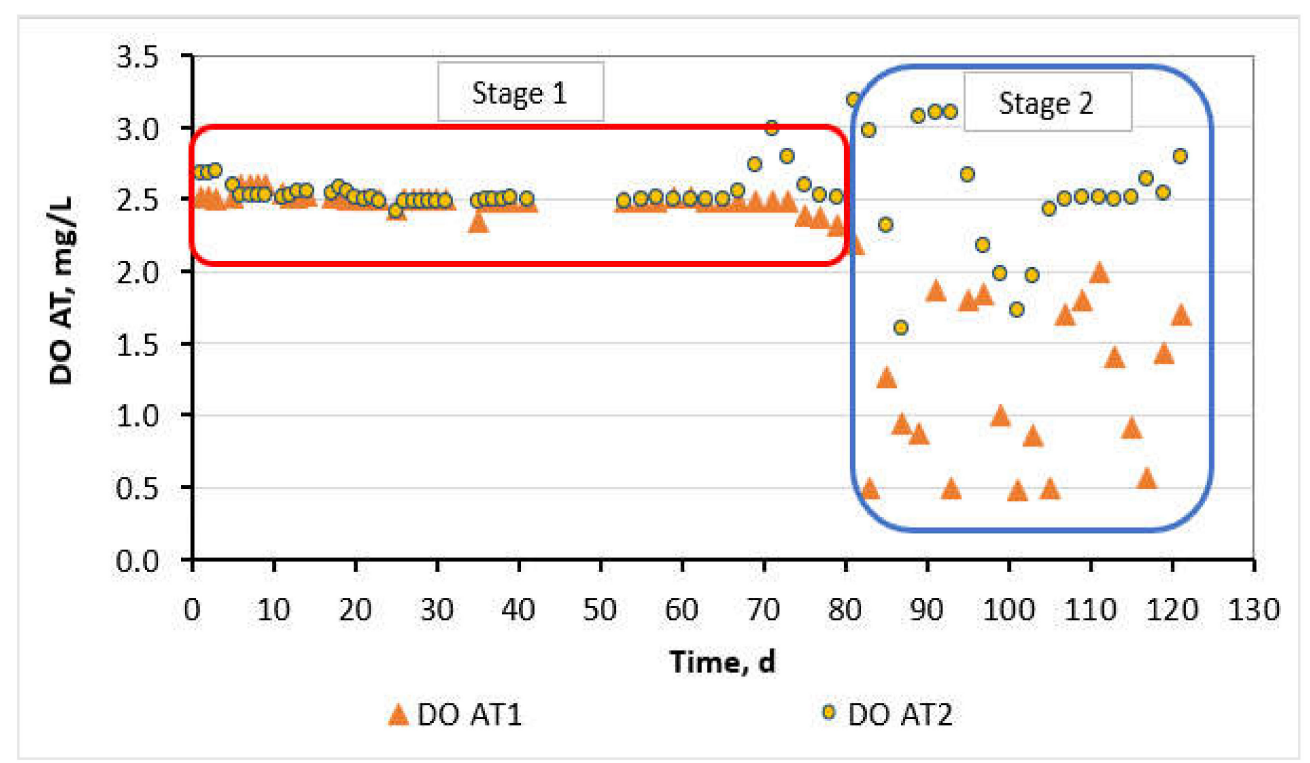

Figure 2. $\mathrm{DO}$ concentration in the $\mathrm{AT}_{1}$ and $\mathrm{AT}_{2}$ chambers at the step-aerating $\mathrm{MBR}$ as a function of the operation time.

The HRT based on $\mathrm{Q}_{\text {in }}+\mathrm{Q}_{\mathrm{r}}$ was $1.6 \mathrm{~h}$ in the $\mathrm{AT}_{1}$ tank, $4.8 \mathrm{~h}$ in the $\mathrm{AT}_{2}$, while the corresponding HRT based only on $\mathrm{Q}_{\text {in }}$ was equal to $5.5 \mathrm{~h}, 17 \mathrm{~h}$ in the $\mathrm{AT}_{1}$ and $\mathrm{AT}_{2}$ respectively, and $28 \mathrm{~h}$ for the whole MBR unit. The sludge retention time was $30 \pm 5 \mathrm{~d}$. The operating parameters in the step-aerating MBR unit compared to the control MBR unit are summarized in Table 1. The HRT values were intentionally given to the MBR unit aiming to keep the membrane fouling rate as low as possible.

\subsection{Transmembrane Pressure (TMP) and Membrane Fouling Profiles}

The TMP profile as a function of the MBR operation time for the step-aerating MBR is presented in Figure 3. According to the blue line of Figure 3, rotations of the $\mathrm{P}_{3}$ pump were gradually automatically increased, aiming to correct the operation of the peristaltic pump and to keep $Q_{\text {eff }}$ constant and equal to $1.1 \mathrm{~L} / \mathrm{h}$ even when membrane fouling was increased. Figure 3 also represents the TMP evolution of the control MBR as a function of operation time.

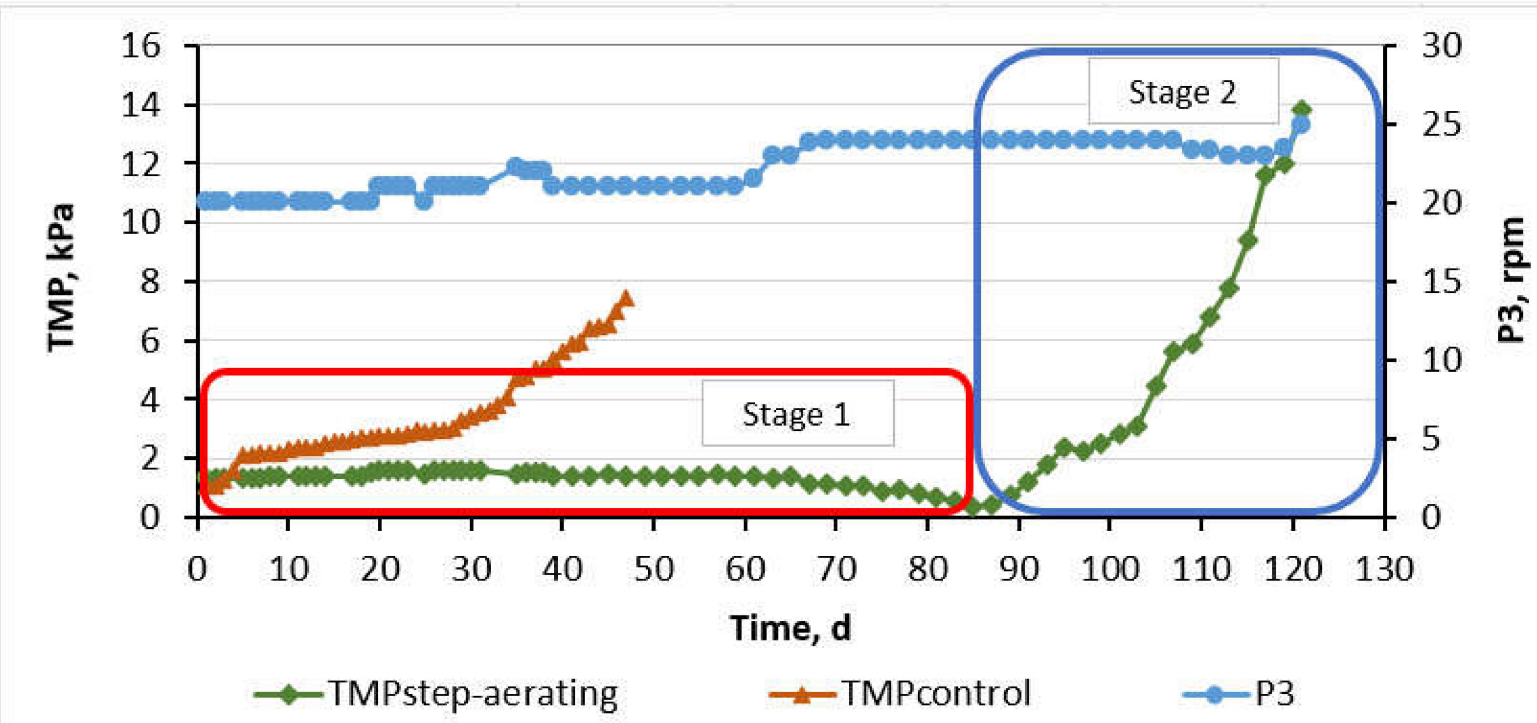

Figure 3. TMP graphs for the step-aerating MBR and control MBR, and peristaltic pump $\mathrm{P}_{3}$ rotations versus the MBR operation time. 


\subsection{Growth, Control and characTerisation of Filamentous Microorganisms}

The filament index in the step-aerating MBR is presented in detail in Figure 4. Following, Figure 5 presents optical microscopy images, where the gradual growth of filamentous microorganisms is presented. Regarding the control MBR, the filamentous population was retained at very low levels of FI $<1.5$.

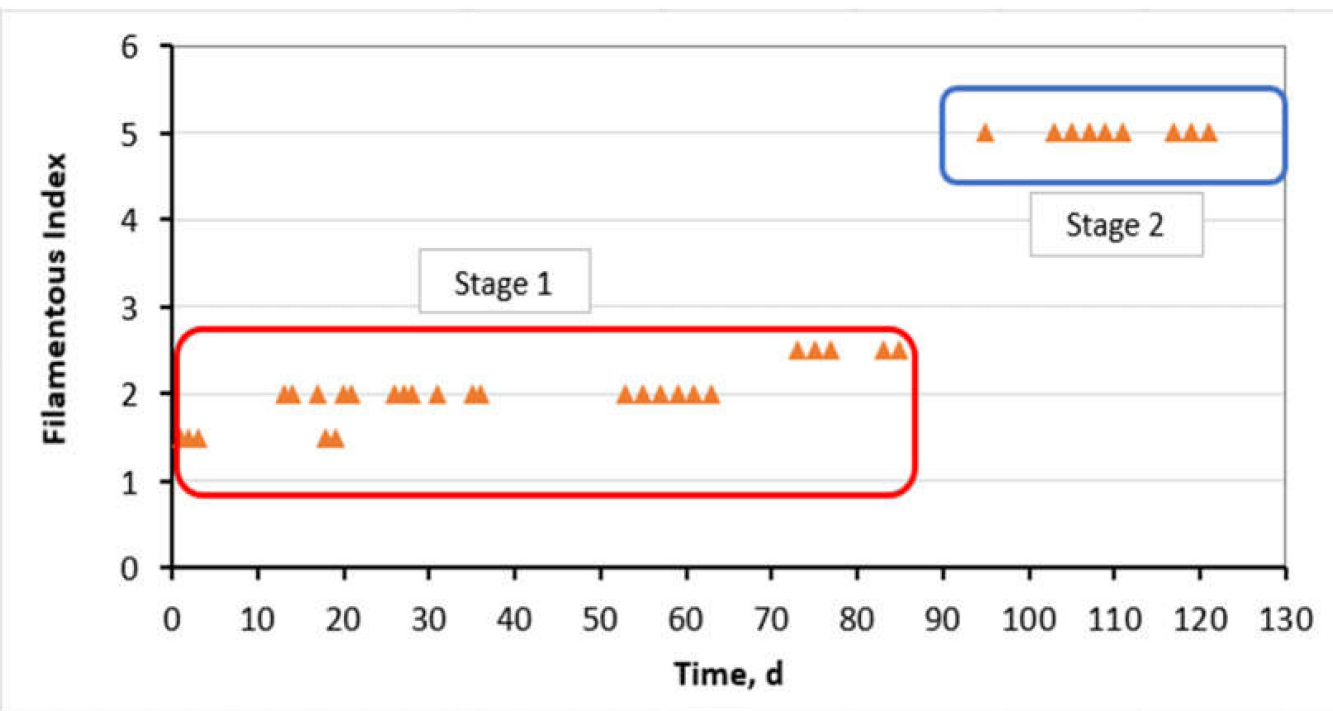

Figure 4. Filamentous index versus the MBR operation time.

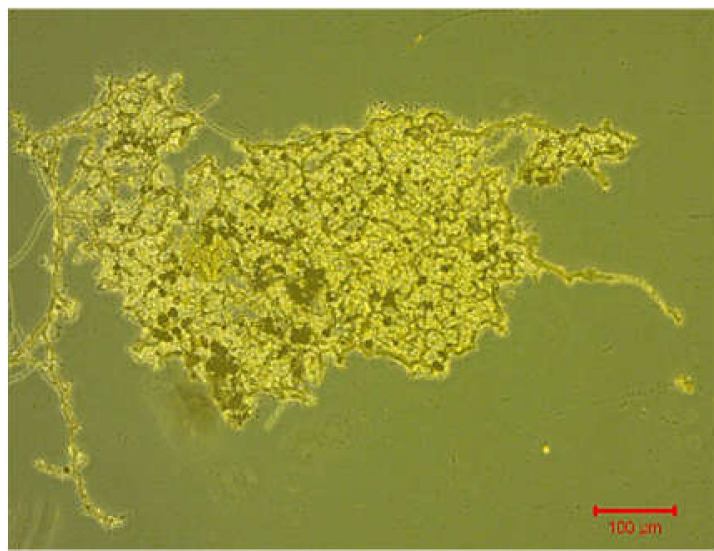

(a)

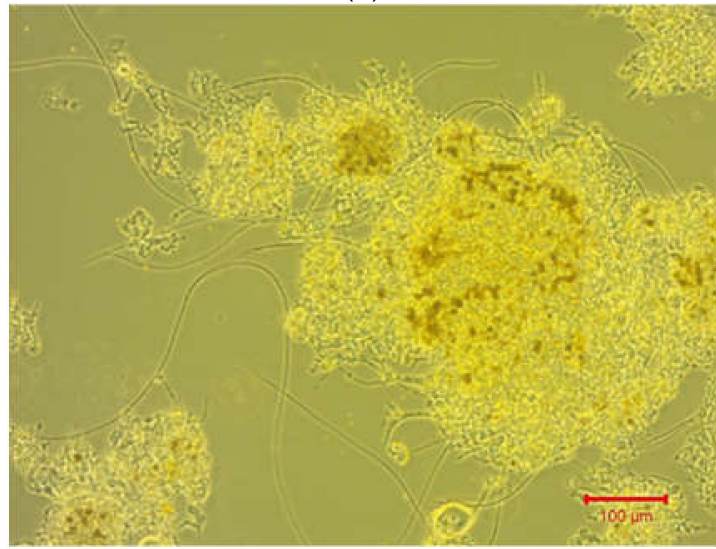

(c)

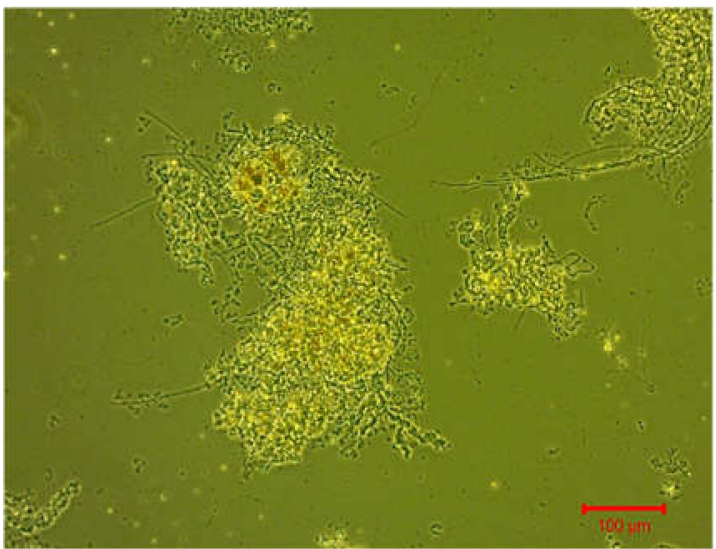

(b)

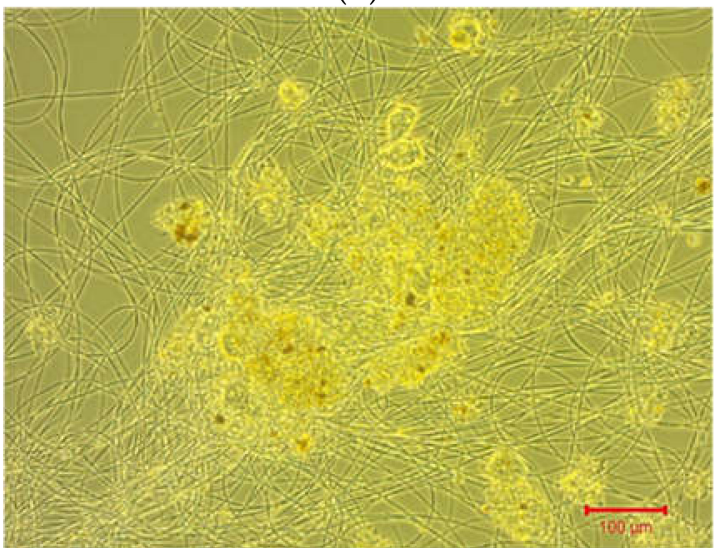

(d)

Figure 5. Optical microscopy images for the activated sludge mixed liquor's samples of the step-aerating MBR, where (a) FI = 1.5 on day 18, (b) FI = 2 on day 27, (c) FI = 2.5 on day 75 and (d) FI = 5 on day 121. 
The day when the maximum membrane fouling was observed in the MBR unit that was the 121 day of MBR operation, the filamentous microorganisms were stained and characterized, aiming to determine the reason for their growth. The greatest population of filamentous microorganisms according to Figure $6 a, b$, was Gram-negative and Neisser positive and they were named as Type 0092 filaments. According to Figure $6 \mathrm{c}, \mathrm{d}$, Thiothrix spp. filaments were, also, detected having a yellow/brown color after Neisser staining. Finally, Figure 6e,f illustrate that the filaments Microthrix parvicella were, also, present in the mixed liquor.

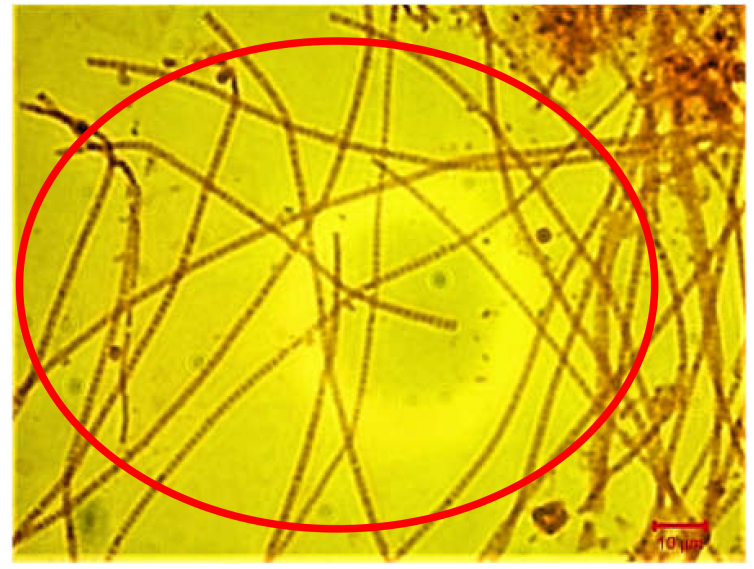

(a)

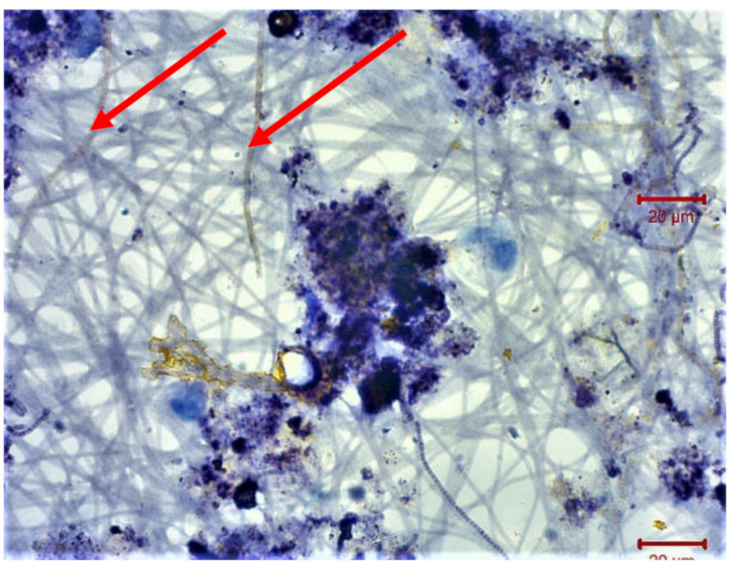

(c)

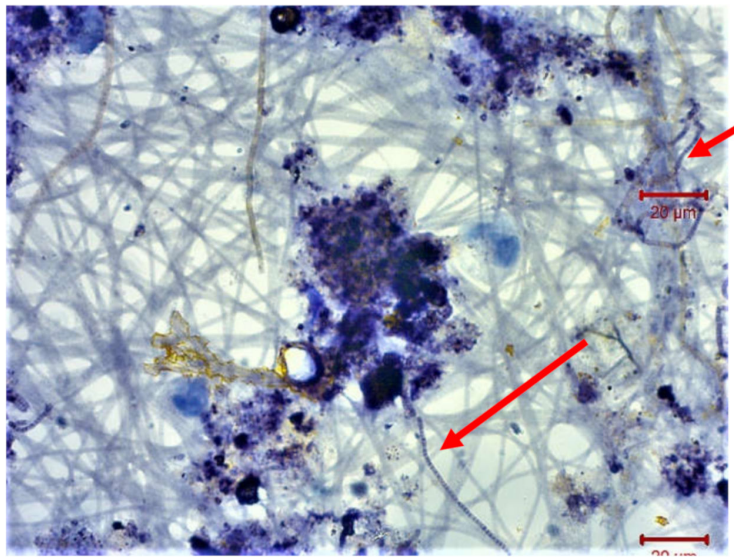

(e)

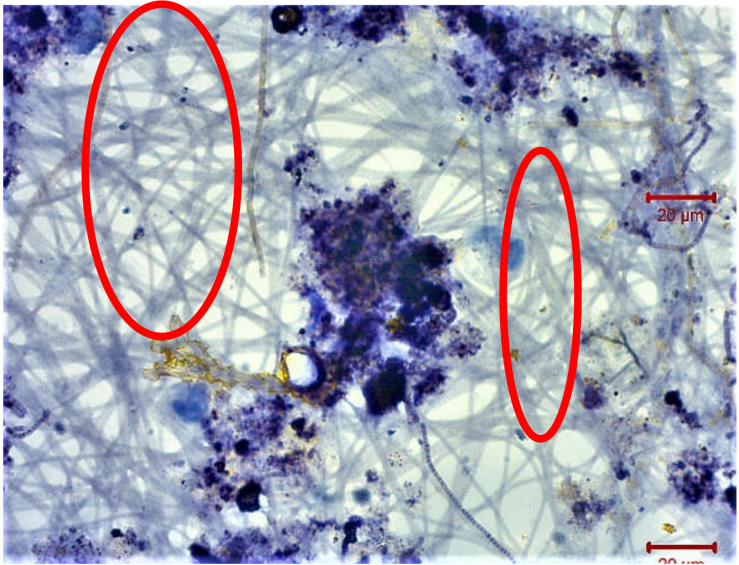

(b)

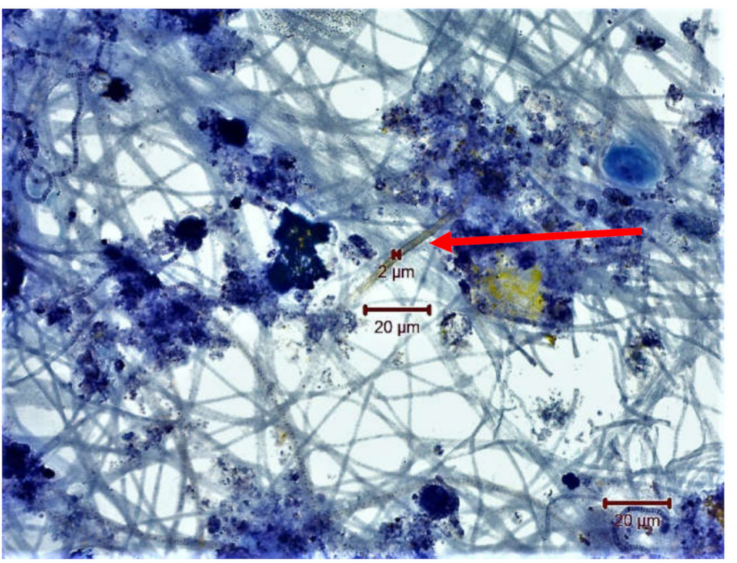

(d)

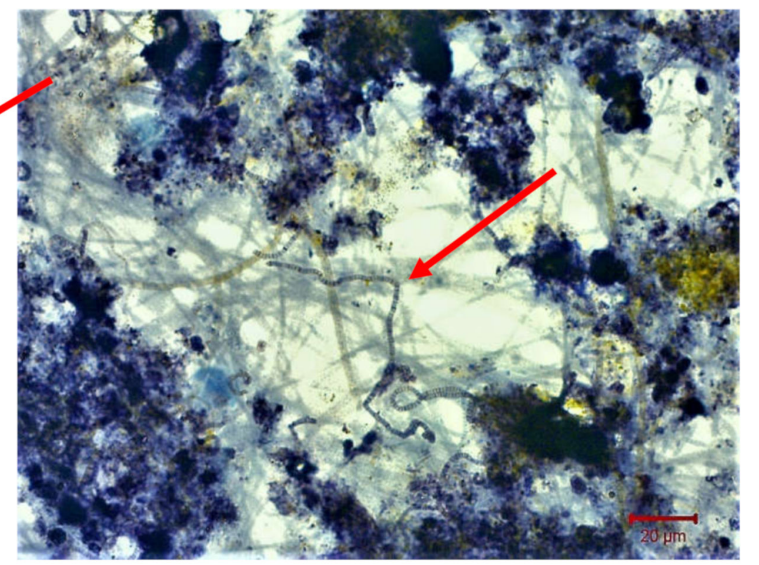

(f)

Figure 6. Optical microscopy images of (a) Gram-negative and (b) Neisser positive filaments named as Type 0092, $(\mathbf{c}, \mathbf{d})$ Neisser negative filaments named as Thiothrix and $(\mathbf{e}, \mathbf{f})$ Neisser negative filaments named as Microthrix parvicella, at the 121st day of the maximum membrane fouling. 


\subsection{SMP Carbohydrates and Proteins Concentrations in the Step-Aerating MBR}

SMP carbohydrates were maintained as low as $8 \pm 6 \mathrm{mg} / \mathrm{L}$ in the step-aerating MBR, as it is presented in Figure $7 \mathrm{a}$, in activated sludge samples coming from the $\mathrm{AT}_{2}$ tank, while in general lines ranged at concentrations smaller than $15 \mathrm{mg} / \mathrm{L}$. A gradual increase of SMP carbohydrates after the first 30 days was attributed to a corresponding gradual increase of MLSS. However, the conclusion was not affected by this incident as their total concentration remained smaller than $15 \mathrm{mg} / \mathrm{L}$. SMP carbohydrates were, also, measured for the $\mathrm{AT}_{1}$ and MT tanks and found similar to the $\mathrm{AT}_{2}$ 's values, as the MBR unit was in balance. SMP carbohydrates in the permeate were found equal to $5 \pm 3 \mathrm{mg} / \mathrm{L}$, which implied that a great part of the SMP passed through the membrane.

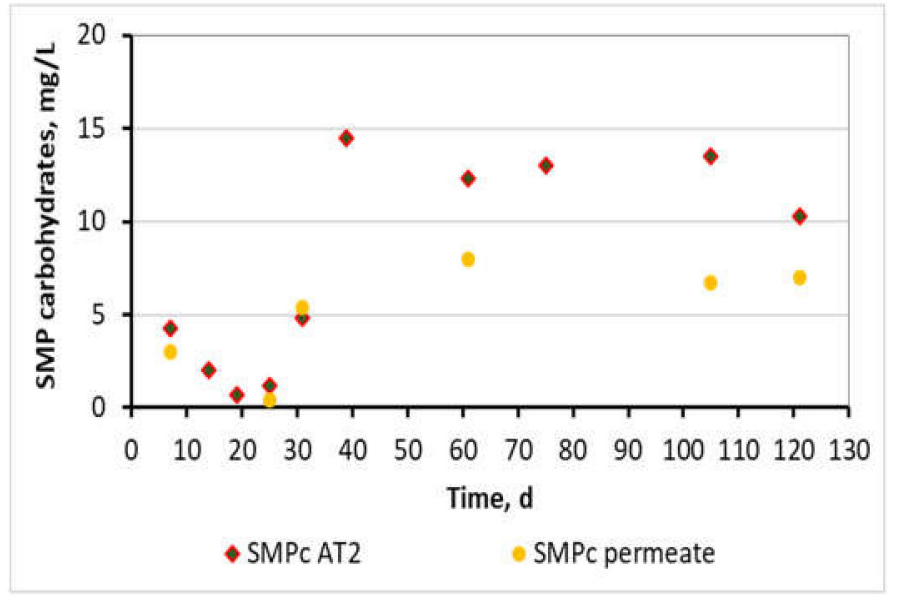

(a)

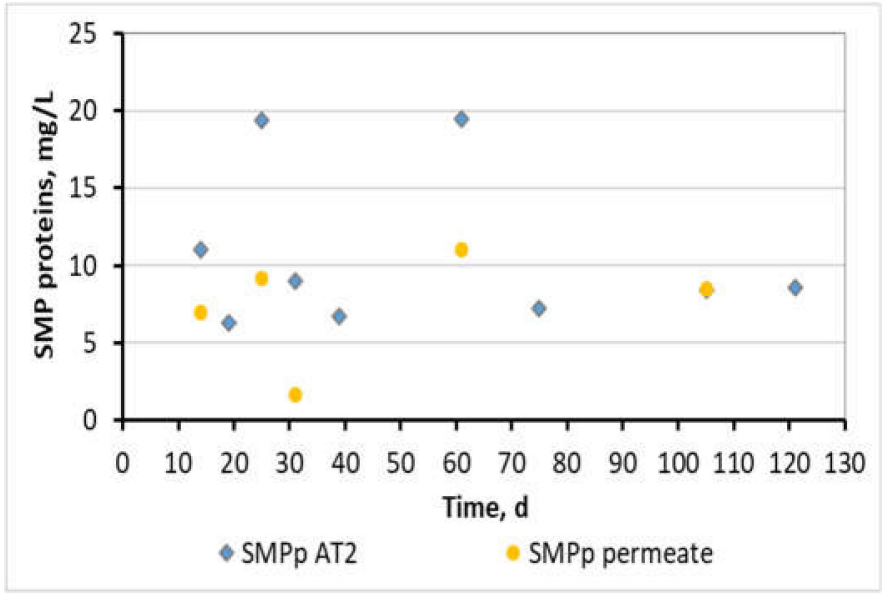

(b)

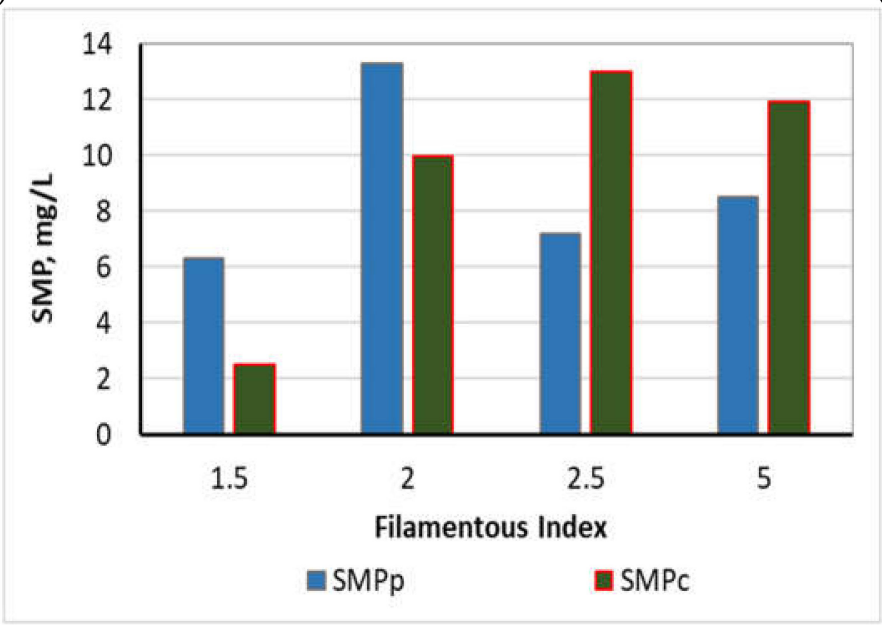

(c)

Figure 7. (a) SMP carbohydrates and (b) SMP proteins in the mixed liquor of the $\mathrm{AT}_{2}$ and in the permeate as a function of the MBR operation time and (c) correlation of SMP concentration with Filamentous Index.

Respectively, SMP protein concentrations were maintained as low as $11 \pm 6 \mathrm{mg} / \mathrm{L}$ (Figure $7 \mathrm{~b}$ ) for activated sludge samples from the $\mathrm{AT}_{2}$, and generally, their concentrations ranged at values below $20 \mathrm{mg} / \mathrm{L}$. Similar SMP protein concentrations were found for the $\mathrm{AT}_{1}$ and MT tanks. SMP proteins in the filtrate were found to be equal to $7 \pm 4 \mathrm{mg} / \mathrm{L}$.

\subsection{Wastewater Treatment Efficiency}

Wastewater treatment efficiency is presented in Table 2 in the form of average \pm standard deviation, regarding chemical oxygen demand (COD), nitrate $\left(\mathrm{NO}_{3}-\mathrm{N}\right)$, ammonium $\left(\mathrm{NH}_{4}-\mathrm{N}\right)$ and total nitrogen (TN) concentrations for the influential wastewater and the effluent permeate. As it is observed, COD removal was excellent, reaching $98 \%$, verifying 
that COD removal was not affected by the increase of filamentous microorganisms. $\mathrm{NH}_{4}-\mathrm{N}$ content was decreased at the effluent and therefore nitrification was efficient. However, $\mathrm{NO}_{3}-\mathrm{N}$ was significantly increased at the effluent because of the absence of an anoxic denitrification step in the wastewater treatment process. TN removal was particularly low, equal to $24 \%$, and it could be attributed to the incorporation into biomass synthesis alone.

Table 2. Wastewater treatment efficiency in the step-aerating MBR.

\begin{tabular}{ccc}
\hline \multirow{2}{*}{ Parameters } & \multicolumn{2}{c}{ Concentration $(\mathbf{m g} / \mathrm{L})$} \\
\cline { 2 - 3 } & Influent & Effluent \\
\cline { 2 - 3 } $\mathrm{COD}$ & $890 \pm 109$ & $15 \pm 5.7$ \\
$\mathrm{NO}_{3}-\mathrm{N}$ & $0.37 \pm 0.21$ & $37 \pm 11$ \\
$\mathrm{NH}_{4}-\mathrm{N}$ & $31 \pm 7.1$ & $0.06 \pm 0.09$ \\
$\mathrm{TN}$ & $63 \pm 7.7$ & $48 \pm 12$ \\
\hline
\end{tabular}

Wastewater treatment regarding the reduction of biological loading in the control MBR was highly effective, as the outflow COD was found equal to $13 \pm 4.2 \mathrm{mg} / \mathrm{L}$. Other physicochemical parameters were not measured in the control MBR as the purpose of its operation was just the comparative study of membrane fouling compared to the stepaerating MBR.

\section{Discussion}

As it can be seen in Figure 3, TMP at Stage 1 was kept under constant control at values lower than $2 \mathrm{kPa}$. Therefore, the significantly high $\mathrm{F} / \mathrm{M}=0.65 \pm 0.2 \mathrm{~g} \mathrm{COD} / \mathrm{g} \mathrm{MLSS} / \mathrm{d}$ in the $\mathrm{AT}_{1}$ of the step-aerating MBR under the imposed operating conditions of $\mathrm{DO}=2.5 \pm 0.1 \mathrm{mg} / \mathrm{L}$ contributed essentially in postponing membrane fouling for more than 3 months (Figure 3 Stage 1), a result further discussed in the following paragraphs. In contrast, the decrease of DO at $1.2 \pm 0.5 \mathrm{mg} / \mathrm{L}$ resulted in an exponential increase of the TMP within a month (Figure 3-Stage 2), a result associated with the growth of filaments. Given the second graph of Figure 3, TMP value was increased rapidly and reached $14 \mathrm{kPa}$ only in $47 \mathrm{~d}$ at the control MBR. Since both MBR units had similar influent COD, MLSS, DO and total F/M loading, it is concluded that the influence of the step-aeration was crucial for the decrease of TMP and the membrane fouling reduction for the step-aerating MBR.

The moderate population of filamentous microorganisms may reduce membrane fouling in MBRs forming sludge of high porosity and low adhesion on the membrane surface $[23,24]$. The step aeration imposed in the MBR unit by dividing the aeration tank into two sub-chambers, $\mathrm{AT}_{1}$ and $\mathrm{AT}_{2}$, as well as the imposed $\mathrm{F} / \mathrm{M}$ and DO values during Stage 1, contributed effectively to the growth of filamentous population in moderate concentrations, corresponding to filamentous index $1.5<\mathrm{FI}<3$ (Figure 4), achieving one of the objectives of this work, to utilize the filamentous bacteria for membrane fouling reduction. Comparing the results of Figures 3 and 4, it is indeed concluded that the control of filamentous microorganisms at moderate concentrations had, as a result, to maintain $\mathrm{TMP}$ at really low values, smaller than $2 \mathrm{kPa}$.

A low total HRT of $18 \mathrm{~h}$ and/or $5 \mathrm{~h}$ in a wastewater treatment process may cause an increase on SMP and growth of filamentous bacteria according to Fallah et al. [32] and Meng et al. [26] respectively. On the other hand, too high HRT also may lead to the accumulation of foulants [26,32]. For these reasons the total HRT at the current study was adjusted at $28 \mathrm{~h}$ (Table 1) aiming not to affect negatively the SMP and filamentous population. The reasoning behind the controlled growth of filamentous bacteria is described as follows. The hydraulic retention time (HRT) was maintained as low as $1.6 \mathrm{~h}$ in the $\mathrm{AT}_{1}$, while a high amount of food was supplied (high $\mathrm{F} / \mathrm{M}=0.45-0.85 \mathrm{~g} \mathrm{COD} / \mathrm{g} \mathrm{MLSS} / \mathrm{d}$ ). In this way, filamentous bacteria were increased easily because of high F/M loading, while biomass activity was decreased because of low HRT. Following, in the $\mathrm{AT}_{2}$, the HRT was increased slightly at $4.8 \mathrm{~h}$ whereas the food supply decreased to a minimum $(\mathrm{F} / \mathrm{M}=0.02-0.04 \mathrm{~g} \mathrm{COD} / \mathrm{g}$ MLSS/d). Therefore, the growing tendency of filamentous 
bacteria was prevented, and their growth was brought under control, as a result of low F/M loading. Furthermore, microorganisms were given time to digest their food and increase the biomass activity, as the HRT was increased marginally. In more detail, the $\mathrm{AT}_{1}$ chamber constituted the critical step, where high rate bio-absorption of organic matter by bacteria and protozoa took place, having, as a result, the restricted bio-absorption (feeding) of the filamentous bacteria that are known for presenting a lower rate of bioabsorption [47]. Therefore, the growth rate of filamentous bacteria was suppressed to the level of $1.5<\mathrm{FI}<3$.

As a result of the imposed operating conditions at the step-aerating MBR and the controlled filamentous growth, the MBR operation was extended for a long period without the need for intermediate chemical cleaning of the used membrane along with less consumed energy, since the pumping through the membrane was carried out with very low TMP. Therefore it could be concluded that the proposed solution of the step-aerating MBR reduces significantly the operating cost of MBR units in general, by minimizing the frequency of chemical cleaning and the frequency of replacement of the fouled membrane as well as by reducing the energy consumed during the filtration. These benefits could be calculated in future research work with a comparable cost analysis regarding the operation of a step-aerating MBR and a conventional MBR comprised of an aeration tank and a membrane tank.

Going back to the operating conditions, low DO concentrations or DO deficiency increase filamentous population in wastewater treatment processes [27-30]. In this study, the decrease of DO concentration at $1.2 \pm 0.5 \mathrm{mg} / \mathrm{L}$ during Stage 2, verified the literature and led to a sharp increase of the filamentous population to $\mathrm{FI}=5$. DO reduction in the $\mathrm{AT}_{1}$ chamber reduced the bio-absorption rate of organic matter by bacteria and protozoa, which favored the parallel bio-absorption of organic matter by the filaments and the increase of their population. Following, the high growth of FI resulted in the aggravation of the membrane fouling (Figure 3), thus verifying other research work [24] and completing other research work [37]. In conclusion, the effect of the high filamentous bacteria population on the membrane-fouling rate was not negligible.

According to Figure 5a-c of optical microscopy, it could be concluded that when filamentous bacteria ranged at $1.5<\mathrm{FI}<3$, they helped to aggregate the sludge flocs and colloids in the mixed liquor acting as a polyelectrolyte, decreasing by this way the TMP and membrane fouling. On the other hand, when filamentous bacteria ranged at $\mathrm{FI}=5$ (abundance of filaments) (Figure $5 \mathrm{~d}$ ), they intensified the dispersion of sludge flocs in the mixed liquor resulting in an inability to bind and aggregate colloids, launching exponentially the TMP and membrane fouling respectively. This conclusion of whether or not the colloidal components were bound on the sludge flocs was particularly important given that the population of colloids plays a decisive and very important role in membrane fouling [13].

According to Figure $6 \mathrm{a}, \mathrm{b}$ the greatest population of filamentous microorganisms were Type 0092 filaments. Type 0092 filaments are mostly straight, irregularly curved or bent, composed of rectangular cells $[27,48]$ and do not present attached growth or a sheath. These bacteria are often found in environments with low food to microorganism $(\mathrm{F} / \mathrm{M})$ ratio $(0.02-0.2 \mathrm{~g} \mathrm{BOD} / \mathrm{g}$ MLSS/d $\approx 0.04-0.4 \mathrm{~g}$ COD/g MLSS/d) and long SRT (10-40 days). Type 0092 prospers in conditions with very similar food sources to M. parvicella but warmer weather conditions. In many treatment plants, the disappearance of M. parvicella in April/May is followed by an increase of Type 0092, as both prefer the same substrate. Type 0092 filaments have been found when the temperature of wastewater is above $15^{\circ} \mathrm{C}$ [27]. In this case, the growth of Type 0092 filaments could be attributed to the low F/M $(0.13 \pm 0.04 \mathrm{~g} \mathrm{COD} / \mathrm{g}$ MLSS/d) ratio in the total MBR unit, in combination with the high SRT equal to $30 \pm 5 \mathrm{~d}$. Moreover, the warm temperature $\left(20 \pm 3^{\circ} \mathrm{C}\right)$ contributed to their growth too.

According to Figure $6 c, d$, Thiothrix spp. filaments were, also, detected. Thiothrix spp. filaments are Gram-negative, Neisser negative (with some Neisser positive granules), 
straight or smoothly curved, with rectangular cells having clear septa without indentations and attached growth. A heavy sheath is possibly apparent and easy to identify because of its large size. Thiothrix spp. are found in environments with low DO [27]. Therefore, the Thiothrix filaments grew in this MBR unit because of the DO decrease in concentration smaller than $2 \mathrm{mg} / \mathrm{L}$ during Stage 2 of the MBR operation (Figure 2).

Finally, Figure 6e,f illustrate that the filaments Microthrix parvicella were, also, present in the mixed liquor. Microthrix parvicella are Gram-positive, Neisser negative, irregularly coiled filaments within the floc or in loose "patches", free in the bulk solution and they do not present any attached growth. M. parvicella are usually present in colder environments at temperatures as low as $7{ }^{\circ} \mathrm{C}$ in pure cultures as well as in full-scale plants [49], while high temperature leads to their decrease [50]. These filaments are usually found in environments where the food to microorganism (F/M) ratio is low $(0.05-0.2 \mathrm{~g} \mathrm{BOD} / \mathrm{g}$ MLSS $/ \mathrm{d}=0.1-0.4 \mathrm{~g}$ $\mathrm{COD} / \mathrm{g}$ MLSS $/ \mathrm{d}$ ) and SRT is not too short ( $>8-10$ days). It has also been found that the $\mathrm{F} / \mathrm{M}$ ratio was negatively correlated with the number of $M$. parvicella gene copies [50]. The growth of M. parvicella, in this MBR unit may be attributed to the same factors as Type 0092 filaments, i.e., the low F/M ratio of $0.13 \pm 0.04 \mathrm{~g}$ COD/g MLSS/d and the high SRT of $30 \pm 5 \mathrm{~d}$. However, their growth was not extensive because of the warm temperatures of $20 \pm 3{ }^{\circ} \mathrm{C}$ in the MBR unit.

According to some research works [25,26], a high Food/Microorganisms (F/M) ratio increases the SMP concentration, resulting in a decrease in sludge filterability. In this study, despite the high F/M loading in the $\mathrm{AT}_{1}(0.65 \pm 0.2 \mathrm{~g} \mathrm{COD} / \mathrm{g}$ MLSS $/ \mathrm{d})$, the soluble microbial products (SMP) were maintained at quite low concentrations, a result that was facilitated by the favorable conditions in the $\mathrm{AT}_{2}$ of $\mathrm{F} / \mathrm{M}=0.03 \pm 0.01 \mathrm{~g}$ COD $/ \mathrm{g}$ MLSS $/ \mathrm{d}$, in conjunction with the high hydraulic retention time in this tank, of $17 \mathrm{~h}$. SMP are gradually deposited and aggregated in the membrane pores causing irreversible membrane fouling [16], therefore the quite low concentrations of SMP contributed additionally to the maintenance of TMP at low prices and therefore to the prolonged fouling reduction.

Moreover, it is concluded that the SMP were not affected by the decrease of DO in the $\mathrm{AT}_{1}$. SMP were neither affected by the increase of filamentous microorganisms from 2 to 5 , as it is presented clearly in Figure 7c, complementing the work of other researchers [38], according to which EPS in the form of proteins and polysaccharides gradually decreased during sludge bulking, while no information was provided regarding SMP. Furthermore, these results verified an older research work [37], according to which filamentous bacteria density had no significant effect on SMP. In conclusion, comparing the results of Figure 7a,b with Figure 3, it appears that the TMP increase during Stage 2 was not attributed to a corresponding increase in SMP but only to the uncontrolled growth of filamentous bacteria.

\section{Conclusions}

According to this research work, it was found that the optimal population of filamentous bacteria of $1.5<\mathrm{FI}<3$ that minimized membrane fouling, was achieved by the imposed conditions in the first aerated bioreactor $\mathrm{AT}_{1}$, where $\mathrm{F} / \mathrm{M}_{\mathrm{AT} 1} \leq 0.65 \pm 0.2 \mathrm{~g}$ $\mathrm{COD} / \mathrm{g} \mathrm{MLSS} / \mathrm{d}$ at a temperature of $20 \pm 3{ }^{\circ} \mathrm{C}$, based on the typical concentration of dissolved oxygen in the wastewater treatment plants of $2.5 \pm 0.1 \mathrm{mg} / \mathrm{L}$ and having a low HRT of $1.6 \mathrm{~h}$. Filamentous bacteria aggregated the sludge flocs and colloids in the mixed liquor, keeping TMP at really low values, smaller than $2 \mathrm{kPa}$, for a great period (3 months), while at the control MBR the TMP was gradually increased reaching $14 \mathrm{kPa}$ in just 1.5 months. After that, the effects of a decrease of the DO concentration in the $\mathrm{AT}_{1}$ at $1.2 \pm 0.5 \mathrm{mg} / \mathrm{L}$ at the step-aerating MBR were checked, which led to a growth of the filamentous population to $\mathrm{FI}=5$. The high growth of the filamentous population resulted in the dispersion of sludge flocs and colloids in the mixed liquor presenting an inability to connect and aggregate, launching exponentially the TMP and membrane fouling respectively. On the last day of total membrane fouling, the types of filamentous microorganisms were identified. The main type of filament detected was Type 0092, while Thiothrix spp. and Microthrix parvicella were also detected. Furthermore, during the entire 
MBR operation period, the SMP were maintained at quite low concentrations, with SMP carbohydrates $<15 \mathrm{mg} / \mathrm{L}$ and proteins $<20 \mathrm{mg} / \mathrm{L}$. The quite low concentrations of SMP contributed additionally to the maintenance of TMP at low prices during Stage 1. SMP were not affected by the decrease of $\mathrm{DO}$ in the $\mathrm{AT}_{1}$, nor by the increase of FI from 2 to 5 during Stage 2. Finally, wastewater treatment performance was excellent.

Supplementary Materials: The following are available online at https://www.mdpi.com/article/10 $.3390 /$ membranes11080553/s1, Table S1: Specifications of the membrane module.

Author Contributions: Funding acquisition, P.S.; Investigation, D.C.B., M.M. and P.S.; Methodology, D.C.B.; Supervision, M.M. and P.S.; Writing-original draft, D.C.B.; Writing-review \& editing, D.C.B., M.M. and P.S. All authors have read and agreed to the published version of the manuscript.

Funding: This research was funded by the European Union and Greek national funds through the Operational Program Competitiveness, Entrepreneurship and Innovation, under the call RESEARCHCREATE-INNOVATE (project code: T1EDK-04370, Reduction of membrane fouling in membrane bioreactors by controlled growth of filamentous microorganisms, FILLAMENTMBR).

Institutional Review Board Statement: Not applicable.

Informed Consent Statement: Not applicable.

Conflicts of Interest: The authors declare no conflict of interest.

\section{References}

1. Isik, O.; Abdelrahman, A.M.; Ozgun, H.; Ersahin, M.E.; Demir, I.; Koyuncu, I. Comparative evaluation of ultrafiltration and dynamic membranes in an aerobic membrane bioreactor for municipal wastewater treatment. Environ. Sci. Pollut. Res. 2019, 26 [CrossRef] [PubMed]

2. Banti, D.; Tsangas, M.; Samaras, P.; Zorpas, A. LCA of a Membrane Bioreactor Compared to Activated Sludge System for Municipal Wastewater Treatment. Membranes 2020, 10, 421. [CrossRef] [PubMed]

3. Meng, F.; Zhang, S.; Oh, Y.; Zhou, Z.; Shin, H.S.; Chae, S.R. Fouling in membrane bioreactors: An updated review. Water Res. 2017, 114, 151-180. [CrossRef]

4. Xiao, K.; Liang, S.; Wang, X.; Chen, C.; Huang, X. Current state and challenges of full-scale membrane bioreactor applications: A critical review. Bioresour. Technol. 2019, 271. [CrossRef]

5. Wu, Y.; Kang, Y.; Zhang, L.; Qu, D.; Cheng, X.; Feng, L. Performance and fouling mechanism of direct contact membrane distillation (DCMD) treating fermentation wastewater with high organic concentrations. J. Environ. Sci. 2018, 65, 253-261. [CrossRef] [PubMed]

6. Winter, J.; Uhl, W.; Bérubé, P.R. Integrated oxidation membrane filtration process-NOM rejection and membrane fouling. Water Res. 2016, 104, 418-424. [CrossRef] [PubMed]

7. Gong, H.; Jin, Z.; Wang, X.; Wang, K. Membrane fouling controlled by coagulation/adsorption during direct sewage membrane filtration (DSMF) for organic matter concentration. J. Environ. Sci. 2015, 32, 1-7. [CrossRef]

8. Lin, H.; Zhang, M.; Wang, F.; Meng, F.; Liao, B.Q.; Hong, H.; Gao, W. A critical review of extracellular polymeric substances (EPSs) in membrane bioreactors: Characteristics, roles in membrane fouling and control strategies. J. Membr. Sci. 2014, 460, 110-125. [CrossRef]

9. Wang, Z.; Mei, X.; Ma, J.; Grasmick, A.; Wu, Z. Potential Foulants and Fouling Indicators in MBRs: A Critical Review. Sep. Sci. Technol. 2013, 48, 22-50. [CrossRef]

10. Chang, H.; Liang, H.; Qu, F.; Ma, J.; Ren, N.; Li, G. Towards a better hydraulic cleaning strategy for ultrafiltration membrane fouling by humic acid: Effect of backwash water composition. J. Environ. Sci. 2016, 43, 177-186. [CrossRef]

11. Tsui, T.H.; Chen, L.; Hao, T.; Chen, G.H. A super high-rate sulfidogenic system for saline sewage treatment. Water Res. 2016, 104, 147-155. [CrossRef] [PubMed]

12. Tsui, T.H.; Ekama, G.A.; Chen, G.H. Quantitative characterization and analysis of granule transformations: Role of intermittent gas sparging in a super high-rate anaerobic system. Water Res. 2018, 139, 177-186. [CrossRef] [PubMed]

13. Banti, D.; Mitrakas, M.; Fytianos, G.; Tsali, A.; Samaras, P. Combined effect of colloids and SMP on membrane fouling in MBRs. Membranes 2020, 10, 118. [CrossRef] [PubMed]

14. Kaewmanee, A.; Chiemchaisri, W.; Chiemchaisri, C.; Yamamoto, K. Treatment performance and membrane fouling characteristics of inclined-tube anoxic/aerobic membrane bioreactor applied to municipal solid waste leachate. Desalination Water Treat. 2016, 57, 29201-29211. [CrossRef]

15. Schmitt, F.; Banu, R.; Yeom, I.T.; Do, K.U. Development of artificial neural networks to predict membrane fouling in an anoxicaerobic membrane bioreactor treating domestic wastewater. Biochem. Eng. J. 2018, 133, 47-58. [CrossRef]

16. Banti, D.C.; Samaras, P.; Tsioptsias, C.; Zouboulis, A.; Mitrakas, M. Mechanism of SMP aggregation within the pores of hydrophilic and hydrophobic MBR membranes and aggregates detachment. Sep. Purif. Technol. 2018, 202, 119-129. [CrossRef] 
17. Chon, K.; Cho, J. Fouling behavior of dissolved organic matter in nanofiltration membranes from a pilot-scale drinking water treatment plant: An autopsy study. Chem. Eng. J. 2016, 295, 268-277. [CrossRef]

18. Gkotsis, P.; Banti, D.; Peleka, E.; Zouboulis, A.; Samaras, P. Fouling Issues in Membrane Bioreactors (MBRs) for Wastewater Treatment: Major Mechanisms, Prevention and Control Strategies. Processes 2014, 2, 795-866. [CrossRef]

19. Meng, F.; Liao, B.; Liang, S.; Yang, F.; Zhang, H.; Song, L. Morphological visualization, componential characterization and microbiological identification of membrane fouling in membrane bioreactors (MBRs). J. Membr. Sci. 2010, 361, 1-14. [CrossRef]

20. Kampouris, I.D.; Karayannakidis, P.D.; Banti, D.C.; Sakoula, D.; Konstantinidis, D.; Yiangou, M.; Samaras, P.E. Evaluation of a novel quorum quenching strain for MBR biofouling mitigation. Water Res. 2018, 143, 56-65. [CrossRef]

21. Li, K.; Wang, J.; Liu, J.; Wei, Y.; Chen, M. Advanced treatment of municipal wastewater by nanofiltration: Operational optimization and membrane fouling analysis. J. Environ. Sci. 2016, 43, 106-117. [CrossRef] [PubMed]

22. Xue, J.; Zhang, Y.; Liu, Y.; Gamal El-Din, M. Effects of ozone pretreatment and operating conditions on membrane fouling behaviors of an anoxic-aerobic membrane bioreactor for oil sands process-affected water (OSPW) treatment. Water Res. 2016, 105, 444-455. [CrossRef]

23. Mitrakas, M.G.; Samaras, P.; Banti, D.C. Method for Fouling Prevention of Membranes in Membrane Bioreactors; European Patent Office (EPO): Berlin, Germany, 2018.

24. Banti, D.C.; Karayannakidis, P.D.; Samaras, P.; Mitrakas, M.G. An innovative bioreactor set-up that reduces membrane fouling by adjusting the filamentous bacterial population. J. Membr. Sci. 2017, 542, 430-438. [CrossRef]

25. Guo, W.; Ngo, H.H.; Li, J. A mini-review on membrane fouling. Bioresour. Technol. 2012, 122, 27-34. [CrossRef] [PubMed]

26. Meng, F.; Shi, B.; Yang, F.; Zhang, H. Effect of hydraulic retention time on membrane fouling and biomass characteristics in submerged membrane bioreactors. Bioprocess Biosyst. Eng. 2007, 30, 359-367. [CrossRef]

27. Eikelboom, D.H. Process Control of Activated Sludge Plants by Microscopic Investigation, 1st ed.; IWA Publishing: Zutphen, The Netherlands, 2000; ISBN 900222299.

28. Jenkins, D.; Richard, M.; Daigger, G. Manual on the Causes and Control of Activated Sludge Bulking, Foaming and other Solids Separation Problems, 3rd ed.; Lewis Publishers: Chelsea, MI, USA, 2003; ISBN 9781843390466.

29. Guo, J.; Peng, Y.; Wang, S.; Yang, X.; Wang, Z.; Zhu, A. Stable limited filamentous bulking through keeping the competition between floc-formers and filaments in balance. Bioresour. Technol. 2012, 103, 7-15. [CrossRef] [PubMed]

30. Martins, A.M.P.; Heijnen, J.J.; Van Loosdrecht, M.C.M. Effect of dissolved oxygen concentration on sludge settleability. Appl. Microbiol. Biotechnol. 2003, 62, 586-593. [CrossRef]

31. Liao, B.Q.; Lin, H.J.; Langevin, S.P.; Gao, W.J.; Leppard, G.G. Effects of temperature and dissolved oxygen on sludge properties and their role in bioflocculation and settling. Water Res. 2011, 45, 509-520. [CrossRef]

32. Fallah, N.; Bonakdarpour, B.; Nasernejad, B.; Alavi Moghadam, M.R. Long-term operation of submerged membrane bioreactor (MBR) for the treatment of synthetic wastewater containing styrene as volatile organic compound (VOC): Effect of hydraulic retention time (HRT). J. Hazard. Mater. 2010, 178, 718-724. [CrossRef]

33. Ouyang, K.; Liu, J. Effect of sludge retention time on sludge characteristics and membrane fouling of membrane bioreactor. J. Environ. Sci. 2009, 21, 1329-1335. [CrossRef]

34. Al-Halbouni, D.; Traber, J.; Lyko, S.; Wintgens, T.; Melin, T.; Tacke, D.; Janot, A.; Dott, W.; Hollender, J. Correlation of EPS content in activated sludge at different sludge retention times with membrane fouling phenomena. Water Res. 2008, 42, 1475-1488 [CrossRef]

35. Ng, K.K.; Lin, C.F.; Lateef, S.K.; Panchangam, S.C.; Hong, P.K.A.; Yang, P.Y. The effect of soluble microbial products on membrane fouling in a fixed carrier biological system. Sep. Purif. Technol. 2010, 72, 98-104. [CrossRef]

36. Wang, X.; Liu, J.; Ren, N.Q.; Yu, H.Q.; Lee, D.J.; Guo, X. Assessment of multiple sustainability demands for wastewater treatment alternatives: A refined evaluation scheme and case study. Environ. Sci. Technol. 2012, 46, 5542-5549. [CrossRef]

37. Li, J.; Li, Y.; Ohandja, D.G.; Yang, F.; Wong, F.S.; Chua, H.C. Impact of filamentous bacteria on properties of activated sludge and membrane-fouling rate in a submerged MBR. Sep. Purif. Technol. 2008, 59, 238-243. [CrossRef]

38. Shen, Y.; Huang, D.M.; Chen, Y.P.; Yan, P.; Gao, X. New insight into filamentous sludge bulking during wastewater treatment: Surface characteristics and thermodynamics. Sci. Total Environ. 2020, 712, 135795. [CrossRef] [PubMed]

39. Yu, W.; Graham, N.J.D.; Fowler, G.D. Coagulation and oxidation for controlling ultrafiltration membrane fouling in drinking water treatment: Application of ozone at low dose in submerged membrane tank. Water Res. 2016, 95, 1-10. [CrossRef] [PubMed]

40. Mustafa, G.; Wyns, K.; Buekenhoudt, A.; Meynen, V. New insights into the fouling mechanism of dissolved organic matter applying nanofiltration membranes with a variety of surface chemistries. Water Res. 2016, 93, 195-204. [CrossRef]

41. Clesceri, S.; Greenberg, E.; Trussell, R. Inorganic Nonmetals, in Standard Methods for Examination of Water and Wastewater, 17th ed.; American Public Health Association: Washington, DC, USA, 1989.

42. Le-Clech, P.; Chen, V.; Fane, T.A.G. Fouling in membrane bioreactors used in wastewater treatment. J. Membr. Sci. 2006, 284, 17-53. [CrossRef]

43. Van der Marel, P.; Zwijnenburg, A.; Kemperman, A.; Wessling, M.; Temmink, H.; van der Meer, W. An improved flux-step method to determine the critical flux and the critical flux for irreversibility in a membrane bioreactor. J. Membr. Sci. 2009, 332, 24-29. [CrossRef]

44. Hwang, B.K.; Kim, J.H.; Ahn, C.H.; Lee, C.H.; Ra, Y.H. Effect of disintegrated sludge recycling on membrane permeability in a membrane bioreactor combined with a turbulent jet flow ozone contactor. Water Res. 2010, 44, 1833-1840. [CrossRef] 
45. DuBois, M.; Gilles, K.A.; Hamilton, J.K.; Rebers, P.A.; Smith, F. Colorimetric Method for Determination of Sugars and Related Substances. Anal. Chem. 1956, 28, 350-356. [CrossRef]

46. Hartree, E.F. Determination of protein: A modification of the lowry method that gives a linear photometric response. Anal. Chem. 1972, 48, 422-427. [CrossRef]

47. Davies, P.S. The Biological Basis of Wastewater Treatment; Strathkelvin Instruments Ltd.: Motherwell, UK, 2005.

48. Insel, G.; Erol, S.; Ovez, S. Effect of simultaneous nitrification and denitrification on nitrogen removal performance and filamentous microorganism diversity of a full-scale MBR plant. Bioprocess Biosyst. Eng. 2014, 2163-2173. [CrossRef]

49. Rossetti, S.; Tomei, M.C.; Nielsen, P.H.; Tandoi, V. "Microthrix parvicella", a filamentous bacterium causing bulking and foaming in activated sludge systems: A review of current knowledge. FEMS Microbiol. Rev. 2005, 29, 49-64. [CrossRef] [PubMed]

50. Fan, N.S.; Qi, R.; Huang, B.C.; Jin, R.C.; Yang, M. Factors influencing Candidatus Microthrix parvicella growth and specific filamentous bulking control: A review. Chemosphere 2020, 244, 125371. [CrossRef] [PubMed] 